DOI https://doi.org/10.30525/978-9934-26-182-4-38

\title{
МЕТОДОЛОГІЧНІ ПІДХОДИ ДО ФОРМУВАННЯ ЗДОРОВ'ЯЗБЕРЕЖУВАЛЬНОЇ КОМПЕТЕНТНОСТІ В УЧНІВ У СУЧАСНІЙ ШКОЛІ
}

\author{
Коцур H. I. \\ доктор історичних наук, професор, \\ завідувачка кафедри медико-біологічних дисииплін і валеології \\ Університет Григорія Сковороди в Переяславі \\ м. Переяслав, Київська область, Украӥна
}

У сучасних умовах реформування освіти в Україні одним із важливих завдань $\epsilon$ збереження і зміцнення здоров'я школярів із урахуванням як педагогічних, так і валеологічних умов, а також відповідального ставлення до індивідуального здоров'я як до найвищої суспільної цінності. У зв'язку з цим виникає потреба у вихованні компетентної особистості, яка не лише володіє знаннями, а й уміє застосовувати їх у житті. Формування компетентностей, необхідних для успішної самореалізації особистості в суспільстві озвучено в Концепції Нової української школи (2016).

Серед головних підходів формування здоров'я учнів у сучасній школі $\epsilon$ компетентнісний підхід, спрямований також, окрім інших, на набуття учнем здоров'язбережувальної компетентності. Саме тому важливою складовою професійної діяльності сучасного педагога $є$ формування здоров'язбережувальної компетентності в учнів. Про формування здоров'язбережувальної компетентності як ключової категорії освіти України підкреслюється науковцем у галузі педагогіки Т. Є. Бойченко [1, с. 6].

Актуальність зазначеної проблеми пов'язана із погіршенням стану здоров'я школярів, яке викликає занепокоєння як у лікарів, так і в педагогів. Неврахування стану здоров'я школярів під час організації освітнього процесу суттєво впливає на їх захворюваність. Інформаційні перевантаження, стресогенні ситуації, комп'ютеризація освітнього процесу вимагають від дитячого організму великого напруження, що, разом із іншими негативними факторами, призводить до різноманітних морфофункціональних порушень, а згодом і до формування органічної патології.

Практична реалізація завдань формування здоров'язбережувального життєвого простору дитини залежить, насамперед, від учителя, завдяки якому процес навчання будь - якій шкільній дисципліні має стати невід'ємною частиною здоров'язбереження учня. Адже вчитель, відповідно до специфіки своєї педагогічної діяльності, може застосувати 140 
комплекс освітніх та виховних ресурсів організації здоров'язбережувальної взаємодії в школі із урахуванням педагогічних умов та комплексного підходу до розв'язання проблеми збереження і зміцнення фізичного, духовного та соціального здоров'я учнів. Водночас це вимагає від учителів пошуку інноваційних підходів та використання таких методик, які б сприяли збереженню здоров'я дітей та формуванню навичок здорового способу життя.

Методологічні підходи до формування здоров'язбережувальної компетентності в учнів розкриті в низці досліджень учених у галузі педагогіки, зокрема О. Безносюк, О. Плахотнік, М. А. Удовенко, Т. П. Суяніна, В. Химинець та ін. Зокрема, в дослідженні М. А. Удовенко висвітлюються методологічні аспекти формування здоров'язбережувальної компетентності в учнів початкової школи в процесі вивчення «Основ здоров'я». Дослідниця особливу увагу зосередила на формуванні в учнів знань про здоров'я та його складових, про здоровий спосіб життя та дотриманні його компонентів, етапах формування здоров'язбережувальної компетентності в учнів [5].

Організаційно-методичний супровід розв'язання зазначеної проблеми розкрито в публікаціях Т. Андрющенко, Є. Дорошенко, І. Звєрєва, Р. Клопова, О. Ковальова, В. Лях, Т. Нікіфорова, В. Пащенко та ін. Науковці акцентували особливу увагу на здоров'язбережувальному аспекті в освіті й особливостях його організації в процесі навчання й виховання учнів.

Проведений нами аналіз літератури щодо впровадження методики формування в учнів здоров'язбережувальної компетентності показав, що на практиці ця робота проводиться епізодично. У зв'язку з цим потребують удосконалення деякі методологічні аспекти зазначеної проблеми. Дослідники С. М. Кондратюк та Г.Л. Праженик виділяють три етапи формування здоров'язбережувальної компетентності в учнів, які відрізняються один від одного як специфічними завданнями, так i особливостями проведення методики [4, с. 105-108]. На першому етапі слід ознайомлювати учнів із основними поняттями та уявленнями з метою формування елементарних знань про компоненти здорового способу життя: знання про елементарні правила збереження і зміцнення здоров'я; виконання норм здоров'язбереження; мотивація до ведення здорового способу життя.

Другий етап формування здоров'язбережувальної компетентності в учнів повинен бути спрямований на поглиблене вивчення і усвідомлення основ здорового способу життя та розв'язання таких завдань: розширення уявлень про основи здоров'язбереження; досягнення свідомого виконання 
елементарних правил збереження та зміцнення здоров'я; формування практичних знань, умінь, навичок, необхідних у повсякденному житті.

На третьому етапі проводиться закріплення знань, умінь і навичок збереження та зміцнення здоров'я, їх подальше вдосконалення щодо формування вміння зберігати здоров'я та закріплення звичкою з метою повсякденного використання. На цьому етапі вирішуються такі завдання: досягнення систематичності та стабільності, автоматичне застосування правил збереження здоров'я; практичне виконання оздоровчих заходів; забезпечення варіативного використання правил здорового способу життя залежно від конкретних практичних умов .

Аналітичний огляд наукових досліджень i сучасної педагогічної практики свідчить, що формування здоров'язбережувальної компетентності здійснюється за допомогою впровадження в освітній процес здоров'язбережувальних технологій, які включають систему наукових знань, сукупність засобів, методів і прийомів, що дозволяють оцінити функціональні та психофізіологічні показники здоров'я індивіда. На ці аспекти наголошують у своїх публікаціях О. Ващенко та С. Свириденко $[2 ; 3]$.

Ураховуючи вищезазначені етапи формування здоров'язбережувальної компетентності в учнів, слід впроваджувати такі форми організації педагогічного процесу, які були б спрямовані на формування валеологічних знань та вдосконалення здоров'язбережувальних практичних навичок учнів. Зокрема, це уроки з фізичної культури, основ здоров'я, екології; фізкультурно-оздоровчі заходи (динамічні паузи, фізкультурні хвилинки на уроках тощо); позакласні заходи (години спілкування, тренінги, одноденні туристичні подорожі тощо) та позашкільна робота (спортивні секції, відвідування басейну, гуртки художньої самодіяльності, різні види танців тощо); спеціально організовані оздоровчі заходи та процедури, малі форми активного відпочинку, що спрямовані на формування культури здоров'я, ведення здорового способу життя, i відповідно сприяють здоров'язбережувальній компетентності.

Проведене нами анкетування учителів початкових шкіл м. Переяслава Київської області показало, що переважна більшість педагогів розуміють важливість проблеми формування в учнів здорового способу життя, але недостатньо володіють методиками здоров'язбереження школярів. У зв'язку з цим нами було наголошено на необхідності конкретизувати педагогічні умови, які будуть цілеспрямовано впливати на формування в учнів молодшого шкільного віку здоров’ язбережувальної компетентності. До таких педагогічних умов нами віднесено: 
1) формування в учнів ціннісного ставлення до здоров'я як найвищої суспільної цінності та мотивації до ведення здорового способу життя;

2) поетапна реалізація методики формування в учнів здоров'язбережувальної компетентності;

3) організація здоров'язбережувального середовища для закріплення учнями життєвих навичок, що сприяють їх фізичному, соціальному, психічному й духовному здоров'ю.

Застосування учнями набутих знань, умінь і навичок здорового способу життя, тобто закріплення здоров'язбережувальних життєвих навичок відбувається лише у спеціально створеному здоров'язбережувальному середовищі. За допомогою такого способу учні можуть самостійно приймати рішення, моделювати свою поведінку, нести відповідальність за свої вчинки тощо. Саме таким чином учні набувають власного досвіду свідомого дотримання основних компонентів здорового способу життя.

Отже, наявне методологічне підгрунтя дає можливість визначити структуру, зміст, функції, критерії сформованості здоров'язбережувальної компетентності педагога, визначити організаційно-педагогічні умови, що сприяють процесу іiі формування в учнів.

\section{Література:}

1. Бойченко Т. Є. Здоров'язберігаюча компетентність як ключова освіти України. Основи здоров'я $i$ фізичної культури. 2008. № 11-12. С.6-7.

2. Ващенко О. М, Свириденко С. Здоров`язберігаючі технології в загальноосвітніх навчальних закладах. Директор школи. 2006. № 20. C. 12-15.

3. Ващенко О., Свириденко О. Готовність вчителя до використання здоров'язберігаючих технологій у навчально-виховному процесі. Основи здоров'я та фізична культура. 2006. №8. С. 1-6.

4. Кондратюк С. М., Праженик Г. Л. Педагогічні умови формування в молодших школярів здоров'язбережувальної компетентності. Педагогічні науки: теорія, історія, інноващійні технології. Суми, 2014, № 9 (43). C.101-108.

5. Удовенко М. А. Методика формування здоров'язбережувальної компетентності учнів початкової школи в процесі вивчення «Основ здоров'я» [Електронний ресурс]. Режим доступу: www.researchgate.net/publication/308783051. 